\title{
Pneumoperitoneum Without Pneumothorax After Blunt Trauma
}

\author{
Künt Travma Sonrası Pnömotorakssız Pnömoperitoneum
}

\author{
Mesut Yur', Mehmet Șirik², Cengiz Ömer Özdemir ${ }^{3}$ \\ ${ }^{1}$ Atatürk Üniversitesi Tip Fakültesi, Genel Cerrabi Anabilim Dal, Erzurum; ${ }^{2}$ Adryaman Üniversitesi Eğitim ve Arastrtrma Hastanesi, \\ Radyoloji Anabilim Dali; ${ }^{3}$ Nöroşirurji Anabilim Dal, Adryaman, Türkiye
}

\begin{abstract}
Pneumoperitoneum usually indicates a surgical emergency because of visceral perforation in 85 to $95 \%$ of cases. Spontaneous pneumoperitoneum without any visceral perforation is a rare condition that surgeons faced with this problem. We reported a case of pneumoperitoneum with burst fracture of thoracic 12nd spine after a blunt trauma. A 27 years old man presented to emergency service after an industrial accident. His Glasgow coma score was 15 and in his abdominal examination, there was tenderness and muscular defense. Ct scan showed us free abdominal air anterior of the liver and burst fracture of thoracic 12nd spine. Firstly, laparotomy was performed but we couldn't observe any identifiable pathology for free air in abdomen. After closure of abdomen, instrumentation was performed for the spine. The patient was discharged on the 4nd postoperative day, but the cause of pneumoperitoneum remained obscure. After blunt trauma without pneumothorax, lonely pneumoperitoneum is a difficult problem for surgeons to operative or conservative treatment.
\end{abstract}

Key words: pneumoperitoneum; blunt trauma; acute abdomen

\begin{abstract}
ÖZET
Pnömoperitoneum, \%85-90 oranında visseral perforasyon olması nedeni ile acil cerrahiyi gerektirir. Visseral perforasyonun olmadı̆̆ı spontan pnömoperitoneum cerrahların karșılaștığı nadir bir durumdur. Bu çalıșmada künt travma sonrası 12. torakal vertebrada çökme fraktürlü pnömoperitoneumu olan bir olgu sunuldu. Endüstriyel bir kaza sonrası acil servise getirilen 27 yașında bir erkek hastada Glasgow koma skoru 15 idi ve karın fizik muayenesinde hassasiyet ve defans vardı. Bilgisayarlı tomografisi 12. torakal vertebrada çökme kırığı ve karaciğer anteriorunda serbest hava gösteriyordu. İk olarak laparotomi yapıldı ancak karın içi serbest havayı açıklayacak bir patoloji bulunamadı. Karın kapatıldıktan sonra vertebra için enstrümantasyon yapıldı. Hasta postoperatif 4. gün taburcu edildi ama pnömoperitoneumun nedeni hala bilinmiyor. Pnömotoraksın olmadığı künt travma sonrası, yalnız pnömoperitoneum, cerrahi veya konservatif tedavi acısından cerrahlar için zor bir durumdur.
\end{abstract}

Anahtar kelimeler: pnömoperitoneum; künt travma; akut karın

Mesut Yur, Atatürk Üniversitesi Araștırma Hastanesi, Genel Cerrabi Kliniŏi 25030 Erzurum - Türkiye, Tel.05058181091Email.mesutyur@hotmail.com Geliş Taribi: 09.04.2016 • Kabul Taribi: 23.01.2017

\section{Introduction}

Pneumoperitoneum (PP) denotes an abnormal collection of air in the peritoneal cavity. It results from a perforation of viscera in $90 \%$ of the cases and requires immediate surgical intervention ${ }^{1}$. Spontaneous pneumoperitoneum (SPP) can be seen in literature ${ }^{2,3}$. But, after blunt trauma, SPP is very rare. In some cases, we can see some PP reports with pneumothorax, pneumomediastinum or pneumocardia although PP has not seen without pneumothorax or with only spine injury $^{1-5}$.

\section{Case Report}

A 27 years old man presented our hospital (Adiyaman University Training and Research Hospital, Department of Emergency Service) 3 hours after a history of blunt trauma which falling down on his back from 2 meters height during his work. His vitals were normal (respiratory rate: $20 / \mathrm{min}$, heart rate: $90 / \mathrm{min}$ and sistolic blood pressure: $130 \mathrm{~mm} \mathrm{Hg}$ ). His coma score was 15 and neurologic examination was normal. His abdomen was distended with features of generalized peritonitis. Rectal examination was unremarkable. Blood tests are; White blood cell: 12000, Hematocrite: 40\%, Hemoglobine: $13 \mathrm{mg} / \mathrm{dl}$.

Urgent computed tomography (CT) performed and it showed us abdominal free air in abdomen (Figure 1,2 ) and burst fracture of 12 th spine (Figure 3). We didn't observe any other pathology. We decided to operate the patient and firstly laparotomy was performed. When we open the abdomen with midline incision, we didn't observe any perforation of viscera and diaphragm. The stomach and duodenum were fully mobilized, and lesser sac was explored, but no 


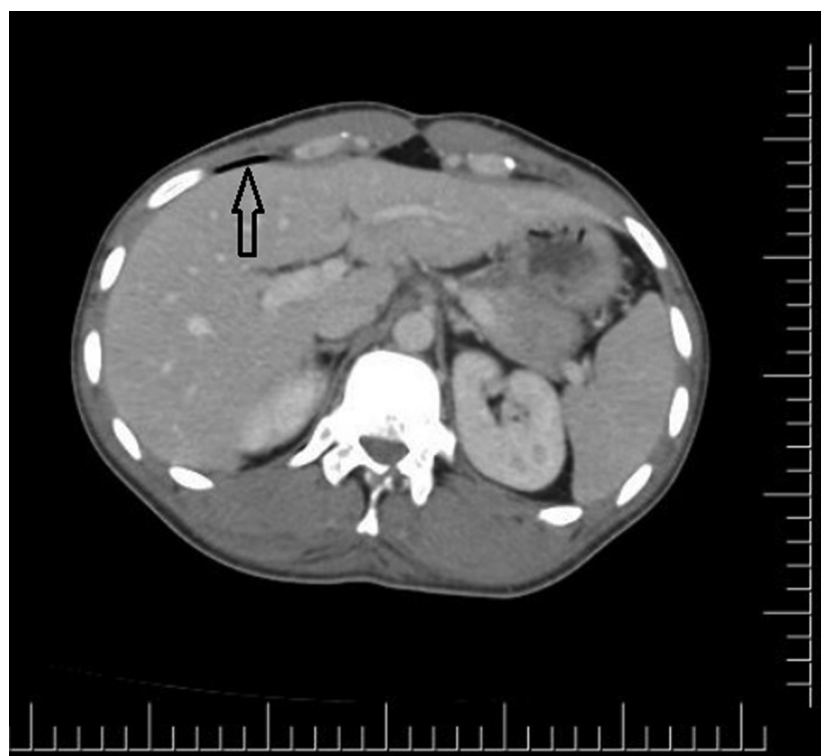

Figure 1. Transverse scan of CT showing (arrow shows the free air anterior of the liver).

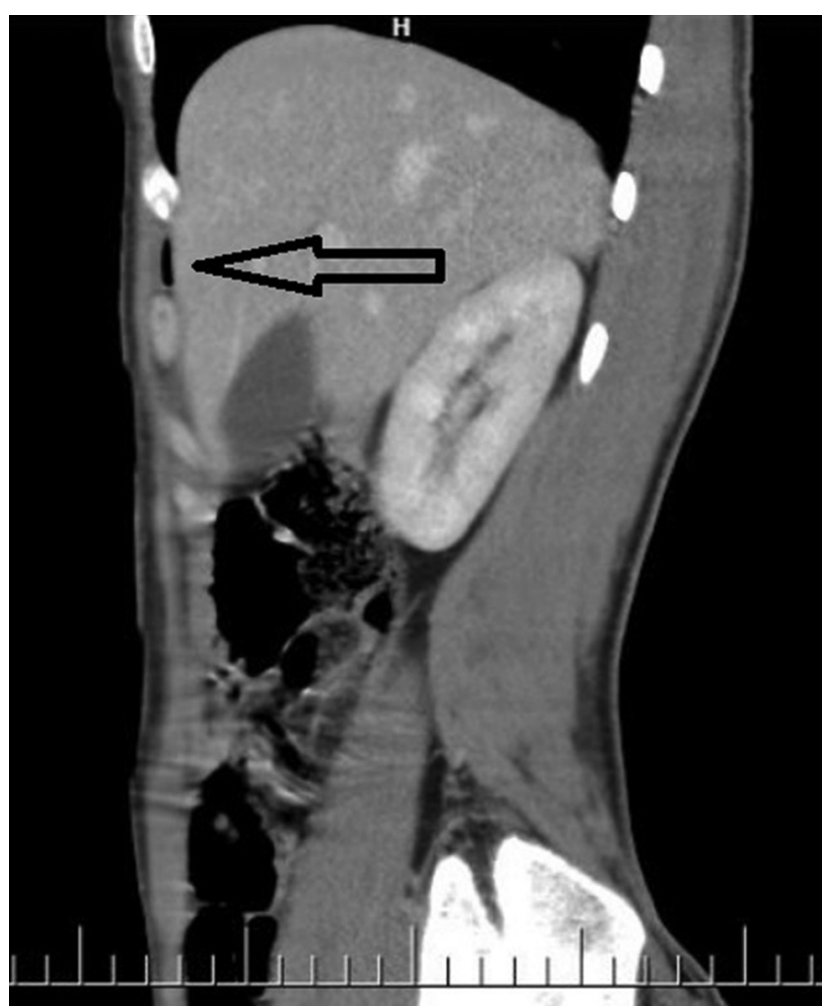

Figure 2. Sagittal scan of CT showing (arrow shows the free air anterior of the liver).

evidence of perforation was found in the distal esophagus, stomach and duodenum. The small bowel and colon also examined, but no leakage was observed and there was no evidence of pneumatosis cystoids intestinalis or other pathologies. Abdominal cavity



Figure 3. CT scan of vertebra (arrow shows the burst fracture of 12th spine).

filled with $2000 \mathrm{cc}$ of normal saline and air was infused through the nasogastric tube into the stomach, but no air leakage was observed in upper gastrointestinal tract. Operation completed by placing a soft drain. After closure of abdomen, spine injury was repaired by specialist of neurosurgery.

The 4th postoperative day, patient discharged with oral nutrition without any complication.

\section{Discussion}

Pneumoperitoneum in trauma patients reliably indicates gastrointestinal perforation in $90 \%$ of cases and usually requires exploratory laparotomy ${ }^{1}$. The other $10 \%$ of them are idiopathic or spontaneous. These cases are air leakage from pneumatosis cystoids intestinalis, a small perforated duodenal ulcer, a leak from colonic diverticulum, insufflation of air through the female genital tract, chronic obstructive pulmonary disease, cardiopulmonary resuscitation, mechanical ventilation, thoracic causes (such as barotraumas), pneumothorax and bronchoperitoneal fistulas.

Intermittent positive-pressure ventilation or thoracic causes (such as barotraumas) may lead to air being introduced into the abdominal cavity by direct passage 
through diaphragmatic and microscopic pleural defects or through the mediastinum along the perivascular connective tissue, traveling retroperitoneally, and then rupturing into the peritoneal cavity.

No definitive explanation exists for the presence of PP in blunt trauma patients without concomitant pneumothorax. The speculation is that the free intraabdominal air in these patients may have resulted from intestinal micro perforations, which rapidly seal and leave behind no obvious clinical sequelae. This is akin to the well-described clinical entity of pneumatosis cystoids intestinalis, which is a rare cause of PP after blunt abdominal trauma ${ }^{6}$.

Pneumoperitoneum, after blunt trauma, can be seen due to many reasons described above. In cases after blunt trauma with pneumothorax-pneumomediastinum and pneumocardia, PP may be seen due to reasons not requiring surgery ${ }^{7-9}$. In most cases, PP has been seen with pneumothorax, pneumomediastinum or pneumocardia. In these cases, they did not find a surgical cause for pneumoperitoneum. Beside these reasons, PP can be seen spontaneously or with other reasons like insufflation of air through the female genital tract, chronic obstructive pulmonary disease, cardiopulmonary resuscitation, mechanical ventilation or others. But we can not see any PP case after blunt trauma like our case that not having pneumothorax, pneumomediastinum or pneumocardia and others causes.

In our case, the patient fell down on his back. PP was observed without pneumothorax and pneumomediastinum after blunt trauma. Furthermore, we didn't observe any other pathologies but for spine injury. So, trauma affected the spine firstly and abdomen affected indirectly. We couldn't say SPP for this patient. Because he was exposed to a blunt trauma.

Nishina et al. suggested non-operative approach in the setting of pneumoperitoneum if the following conditions are present; a thorough physical examination, no peritoneal signs, pneumothorax, negative diagnostic peritoneal lavage and gastrointestinal swallow series, no intraperitoneal effusion on ultrasonography or CT scan and close observation with repeated physical examinations and ultrasonography ${ }^{10}$. To rule out bowel leak, imaging with oral contrast may be needed. However, it may not be informative as the leak may be too small, it may have sealed, it may take long time to opacify the bowel, and the patient may be uncooperative.
Marek et al. evaluated 78 cases and concluded that CT scans may detect free air that is not always clinically significant. Of note, free fluid, seatbelt sign or radiographic signs of bowel trauma in the presence of pneumoperitoneum is highly predictive of injury and these patients should be explored ${ }^{11}$.

With these information, PP after blunt trauma is a serious problem for surgeons. When there is no pneumothorax, pneumomediastinum or pneumocardia, we think that there may be a surgical cause. Because we can see free air in abdomen with pneumo-mediastinum-cardium-thorax. We can follow these patients conservatively under light of literature. But without these conditions, there may be a surgical cause. After knowing this patient, it becomes more difficult to decide a decision for PP after blunt trauma.

\section{Conclusion}

Pneumoperitoneum can be seen in many conditions. We can treat some PP patient conservatively when diagnose includes pneumothorax, pneumomediastinum, chronic obstructive pulmonary disease, cardiopulmonary resuscitation, mechanical ventilation or other knowing causes. But, if there is no explanatory cause, do we have to operate the patient to avoid missing intraabdominal injuries? We may not operate these patients and treat with conservative methods. But, it is a very difficult decision for surgeons treating conservatively without any explanatory causes like pneumothorax or pneumomediastinum after blunt trauma like this case. Conservative management for pneumoperitone$\mathrm{um}$ in the absence of viscus perforation is a safe option in carefully selected cases.

\section{References}

1. MD magazine, Idiopathic pnemoperitoneum after blunt chest trauma, http://www. mdmag. com/journals/surgical-roun ds/2008/2008-04/2008-04_02/;2008.

2. Pitiakoudis M, Zezos P, Oikonomou A, Kirmanidis M, Kouklakis G, Simopoulos C. Spontaneous idiopathic pneumoperitoneum presenting as an acute abdomen: a case report. J Med Case Rep 2011;5:86.

3. Mularki RA, Mularski RA, Ciccolo ML, Rappaport WD. Nonsurgical causes of pneumoperitoneum. West J Med 1999;170(1):41-6.

4. Nayak Samir R, Anindita Mishra, Soren Dilip Kumar, S. Nagendra Babu Spontaneous pneumoperitoneum following blunt trauma chest - diagnostic dilemma - role of diagnostic laparoscope - a case report IJCRR 2013;5(10):51-6. 
5. Di Saverio S, Filicori F, Kawamukai K, Boaron M, Tugnoli G. Combined pneumothorax and pneumoperitoneum following blunt trauma: an insidious diagnostic and therapeutic dilemma. postgrad med j 2011;87:75-8.

6. Gantt CB Jr, Daniel WW, Hallenbeck GA. Nonsurgical pneumoperitoneum. Am J Surg 1977;134(3):411-4.

7. O. Anderson, A. Yaakub, A. Sinha. Pneumoperitoneum associated with pneumopericardium and pneumomediastinum following blunt chest trauma. Injury Extra 2007;38:439-41.

8. Marco Assenza, Fabiola Passafiume, Lorenzo Valesini, Leonardo Centonze, Valentina Romeo, Claudio Modini. Pneumomediastinum and Pneumoperitoneum after Blunt Chest Trauma: The Macklin Effect. J Trauma Treatment 2012;1:107.
9. Ahmad R, Mohamad N, Latiff AKA, Ahmad Z, Idrus II. Pneumoperitoneum following blunt abdominal injury: Does it warrant laparotomy? International Journal of Case Reports and Images 2011;2(12):23-7.

10. Nishina M, Fujii C, Ogino R, Kobayashi R, Kohama A. Pneumoperitoneum and pneumoretroperitoneum in blunt trauma patients. J Trauma 2000;49:565-6.

11. Marek AP, Deisler RF, Sutherland JB, Punjabi G, Portillo A, Krook J, et al. CT scan-detected pneumoperitoneum: an unreliable predictor of intra-abdominal injuryin blunt trauma. Injury 2014;45(1):116-21. 